wide range of $\mathrm{D} / \mathrm{L}$ aspartic acid ratios, even from a single parchment fragment probably precludes the use of this technique for absolute age determination of parchment.

STEPHEN WEINER*

Zina KustanOVICH ${ }^{\dagger}$

Emanuel Gil-Av† Wolfie Traub

* Isotope, $\dagger$ Organic Chemistry and

* Structural Chemistry Departments, Weizmann Institute of Science,

Rehovot, Israel

\section{Nuclear winter and the greenhouse effect}

SIR-Ever since its original publication', the nuclear winter concept has been in dire need of some form of experimental verification. So great has its need for independent corroboration been, in fact, that when challenged on this point ${ }^{2.3}$, the concept's creators responded by grasping at some very strange straws. For one thing, they stated that the climate model they used to develop the concept was only partly calibrated, and that this calibration was accomplished by means of the possible collision of an asteroid or cometary nucleus with Earth at the time of the Cretaceous/Tertiary transition and by research on martian dust storms ${ }^{4}$. To my mind, a much more timely and down-toearth phenomenon to use as a means of calibration is the $\mathrm{CO}_{2}$ greenhouse effect; for it pertains to our own planet, is supposed to be happening now, and is itself predicted by the same climate models that produced the nuclear winter concept.

What are the fruits of such a calibration exercise? From data and equations in the US National Research Council's most recent review of the $\mathrm{CO}_{2} /$ climate connection $^{5}$, it can be calculated ${ }^{6}$ that between 1880 and 1980 the northern third of the Earth (the most climatically sensitive region) should have warmed by about $3^{\circ} \mathrm{C}$ due to atmospheric $\mathrm{CO}_{2}$ increases experienced over that period. However, the true model-predicted warming over this time span is actually $6^{\circ} \mathrm{C}$; for an important study of the past year ${ }^{7}$ has clearly demonstrated that increases in other trace gases over the past 100 years should have had just as great an effect on the Earth's climate as did increases in $\mathrm{CO}_{2}$ during that time.

So how does this $6^{\circ} \mathrm{C}$ warming prediction compare with reality? Recent studies of Arctic and Northern Hemisphere temperature trends of the past century ${ }^{8.10}$ show that the prediction is fully an orderof-magnitude too large, so it is logical to assume that the nuclear winter prediction is similarly overestimated.

Additional support for this conclusion comes from several climate modelling studies of the past two years, which have shown that when more realistic parameterizations of several real-world pro- cesses are included in the models, the climate sensitivity of the Earth is greatly reduced. Somerville and Remer" ${ }^{\prime \prime}$, for instance, have introduced a cloud liquid water content effect which halves climate sensitivity; while Spelman and Manable ${ }^{12}$ and Wang et al. ${ }^{13}$ have improved upon the treatment of feedbacks from meridional and vertical dynamical heat fluxes, including ocean currents, reducing it by a factor of four. Finally, Ou and $\mathrm{Liou}^{14}$ have improved on the treatment of cumulus convection, reducing the climate sensitivity by another 40 per cent. Taken together, these independent model improvements lead to the same order-of-magnitude reduction in the strength of the $\mathrm{CO}_{2}$ greenhouse effect that is suggested by the temperature history of the Earth.

Why do we not see reference to these developments in the public dialogue over the $\mathrm{CO}_{2}$ /climate question? Is it because their acknowledgement would cast doubt on the nuclear winter hypothesis? These are questions that all who are truly concerned about mankind's future on our fragile planet must ask themselves. As Maddox ${ }^{3}$ has rightly said with respect to the effort to avert nuclear war, "by clouding the case with disputable predictions, they [the nuclear winter protagonists] are in danger of weakening it".

S.B. IDso

US Water Conservation Laboratory,

4331 E. Broadway,

Phoenix, Arizona 85040, USA

1. Turco, R.P., Toon, O.B., Ackerman, T.P., Pollack, J.B. \& Sagan, C. Science 222, 1283-1292 (1983)

2. Maddox, J. Nature 307, 107 (1984).

3. Maddox, J. Nature 308. 11 (1984).

4. Turco, R.P., Toon. O.B. Ackerman. T.P., Pollack, J.B. \& Sagan, C. Nature 311, 307-308 (1984)

5. Carbon Dioxide Assessment Committee, US National Research Council Changing Climate (National Academy Press, Washington, DC, 1983)

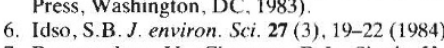

7. Ramanathan, V., Cicerone, R.J.. Singh, H.B. \& Kiehl, J.T. J. geophys. Res. 90, 5547-5566 (1985).

8. Jones, P.D., Wigley, T.M.L. \& Kelly, P.M. Mon. Weath Rev. 110, $59-70$ (1982)

9. Kelly, P.M., Jones, P.D., Sear, C.B., Cherry, B.S.G. \& Tavakol, R. K. Mon. Weath. Rev, 110, 71-83 (1982).

10. Raper, S.C.B. et al. Nature 306, 458-459 (1983)

11. Somerville, R.C.J. \& Remer, L.A. J. geophys. Res. 89 9668-9672 (1984).

12. Spelman, M.J. \& Manabe, S. J. geophys. Res. 89, 571-586 (1984).

13. Wang. W-C., Molnar, G., Mitchell, T.P. \& Stone, P.H. J. geophys. Res. 89, 4699-4711 (1984)

14. Ou. S.S. \& Liou. K-N. J. geophys. Res. 90, 2223-2232 (1985)

\section{Competition amongst desert perennials}

SIR-In his News and Views article on regularity in the desert shrub Larrea tridentata, Silvertown' ignores some areas of current debate and seems to draw spurious analogies between intra-specific competition in plants and inter-specific competition in animals. Intra-specific interactions amongst animals may sometimes create regular spacing ${ }^{2,3}$.

King and Woodell ${ }^{4}$ explicitly stated how the competition hypothesis could account for regularity in desert perennials. The elimination of small individuals by root competition with neighbours could convert a clumped population first to a random and then to a regular pattern. Silvertown not only ignores this hypothesis but also states that no hypothesis was provided to explain regularly-spaced clumps. King and Woodell ${ }^{4}$ added that some regular patterns may have originated during long droughts, when intra-specific competition for water would be at its most intense. This is not 'acknowledging the importance of other factors" as drought will inevitably intensify competition for water.

Larrea tridentata populations develop over such long time spans $s^{5}$ that the hypothesis that regularity is largely due to competition for water will be difficult to disprove. Genets of Larrea can live for up to 11,000 years $^{6}$, the shrub grows slowly, and intense droughts are sporadic. Thus the lack of major change in the patterns of $L$. tridentata over 45 years in an area of fairly high rainfall ${ }^{7}$ is unremarkable and provides no evidence for or against any of the hypotheses which suggest how regular patterns might arise.

The effects of factors other than competition for water on pattern in Larrea, such as allelopathy ${ }^{8}$ and run-off ${ }^{4}$, have been discussed for a long time. Nevertheless, there is regularity in single-species populations of other dryland perennials ${ }^{10}$. It has been shown that adjacent shrubs of L. tridentata compete for water ${ }^{11.12}$. Any refinement of the hypothesis must include (1) the clonal growth pattern of $L$. tridentata in certain sites, (2) the possibility that seedlings become preferentially established on mounds remaining after clumps have died, thus perpetuating existing patterns $s^{13,14}$ and (3) protection of young plants by older plants against freezing ${ }^{14}$.

At some sites clumps which consist of mixtures of genets may have been classified as individuals. The regularity of the clumps still needs an explanation, howev$\mathrm{er}$, whether a clump consists of one genet or several.

T.J. KING S.R.J. WOODELL

Department of Plant Sciences,

South Parks Road,

Oxford $O X 13 R B, U K$

1. Silvertown, J.W. Nature 316, 298 (1985).

2. King, T.J. J. Ecol. 65, 235 (1977)

3. Nelson, J.B. The Sulidae (Oxford University Press 1978)

4. King, T.J. \& Woodell S.R.J. J. Ecol. 61, 761 (1973).

5. Sternberg, L. Madrono 23, 408 (1976)

6. Vasek, F.C. Am. J. Bot 67, $246(1980)$

7. Schlesinger, W. \& Jones, C. Bot. Gaz. 145, 116 (1984)

8. Knipe, D. \& Herbel, C.H. Ecology 47, 775 (1966).

9. Anderson, D.J. J. Ecol. 59, 555 (1971).

10. King, T.J. \& Woodell, S.R.J. J. Ecol. 72, 295 (1984)

11. Fonteyn, P.J. \& Mahall, B.E. Nature 275. 544 (1978)

12. Fonteyn, P.J. \& Mahall, B.E. J. Ecol. 69, 883 (1981)

13. Wright, R.A. Arizona Acad. Sci. 6, 58 (1970)

14. MacMahon, J.A. \& Schimpf, P.F. in Water as a Factor in the Biology of North American Desen Plants (eds Evans D.D. \& Thomas, J.L.) 114 (Dowden, Hutchinson \& Ross, Stroudsberg, Pennsylvania, 1981). 